\title{
POSISI TAFSIR MISTIS FENOMENOLOGI SIMBOLIK DALAM KERANGKA TAFSIR KONVENSIONAL
}

\author{
Nunung Lasmana \\ STAI Asy-Syukriyah Tangerang \\ lasmananunung90@gmail.com
}

\begin{abstract}
This article discusses the phenomenology of symbolic interpretation that leads to a symbolic interpretation of the format and structure of the Koran, such as the meaning behind the letters Hijaiyyah, the figures in the Qur'an, the number of verses of the Koran, the name -the name of the letter, the composition of juz (division) of the Koran, and the 'ain. Efforts to this interpretation comes from a mystical experience endured by Lukman Abdul Qahar Sumabrata. However, the methodology offered by Sumabrata is very controversial because it differs significantly from the methods of interpretation adopted by the conventional commentators. Object methods phenomenological interpretation of symbolic language is not verbal, but symbols and structures of the Koran contained in Ottoman manuscripts.
\end{abstract}

\section{Abstrak}

Artikel ini membahas tafsir fenomenologi simbolik yang mengarah kepada penafsiran secara simbolik terhadap format dan struktur alQur'an, seperti makna di balik huruf-huruf Hijaiyyah, angka-angka dalam al-Qur'an, jumlah ayat al-Qur'an, nama-nama surat, susunan juz (pembagian) al-Qur'an, dan tanda 'ain. Upaya penafsiran ini bersumber dari pengalaman mistis yang dialami oleh Lukman Abdul Qahar Sumabrata. Namun, metodologi yang ditawarkan oleh Sumabrata ini sangat kontroversial karena berbeda secara signifikan dengan metode penafsiran yang dianut oleh para mufassir konvensional. Objek metode tafsir fenomenologi simbolik bukanlah bahasa verbal, melainkan simbol dan struktur al-Qur'an yang tertuang dalam Mushaf Utsmani.

Kata Kunci: Tafsir, Fenomenologi, Simbolik, Mistis. 


\section{Pendahuluan}

Di tengah maraknya kajian tafsir di tengah umat Islam, studi tafsir tentang mushaf atau aspek simbolik format al-Qur'an masih sangat minim dilakukan oleh para ahli tafsir. Dapat dikatakan masih menjadi suatu hal langka yang belum banyak diketahui oleh khalayak umum. ${ }^{1}$ Di samping format mushaf al-Qur'an yang sangat beragam. ${ }^{2}$ Maka dari itulah perhatian para pengkaji al-Qur'an lebih terpacu pada makna dibalik kandungan ayat-ayat al-Qur'an ketimbang pada format dan struktur mushaf al-Qur'an.

Namun, pada dekade 1970-an kajian tafsir al-Qur'an di Indonesia tampil dengan beragam kecenderungan. ${ }^{3}$ Pada akhirnya muncul sebuah metode penafsiran sebagai upaya pertama di Indonesia dalam menafsirkan al-Qur'an dengan memperhatikan aspek fenomenologi dan psikologi al-Qur'an. ${ }^{4}$ Upaya ini dilakukan oleh Lukman Abdul Qohar Sumabrata, Lukman Saksono, dan Anharudin. Mereka menguraikan metode itu dalam karyanya yang berjudul Pengantar

${ }^{1} \mathrm{Hal}$ ini disebabkan, studi al-Qur'an pada umumnya didasarkan asumsi bahwa al-Qur'an merupakan kitab berisi kumpulan ayat (bahasa verbal). Baca, Lukman Abdul Qahar Sumabrata (dkk.), Pengantar Fenomenologi al-Qur'an Dimensi Keilmuan di Balik Mushaf Utsmani, hlm. 12. Secara umum istilah verbal tidak digunakan karena memang dalam setiap kajian tidak dinyatakan, namun disebutkan demikian untuk memudahkan pengertian tentang klasifikasi yang dinotasikan pada notasi simbol. Kajian yang dikelompokan pada paradigma verbal lebih dikenal dalam pendekatan berbagai disiplin ilmu, seperti sejarah, hukum, bahasa, dan lain sebagainya. Lihat: Iskandar Ag. Sumabrata, Pesan-pesan Numerik al-Qur'an (Jakarta: Republika, 2006), v.

${ }^{2} \mathrm{H}$. Ziyad Ul-Haq At-Tubany, Srtuktur Matematika al-Qur'an, 56.

${ }^{3}$ Islah Gusmian, Khazanah Tafsir Indonesia Dari Hermeneutik Hingga Ideologi (Jakarta Selatan: Teraju, 2003), 49-50.

${ }^{4}$ Yang dimaksud dengan tafsir fenomenologi simbolik di sini adalah penafsiran yang dilakukan untuk menemukan pesan-pesan keilmuan di balik unsur-unsur simbolik dalam al-Qur'an, seperti huruf, angka, surat, juz, dan tanda 'ain. Lihat. Lukman Abdul Qahar Sumabrata (dkk.), Pengantar Fenomenologi alQur'an Dimensi Keilmuan di Balik. Mushaf Usmani (Jakarta: Grafikatama Jaya, 1991), hlm. 14. Terkait dengan kajian ini, Lukman menganggap bahwa ada beberapa permasalahan yang belum terjawab, yaitu: Pertama, Benarkah al-Qur'an itu hanya terdiri dari susunan ayat yang jumlahnya 6236? Kedua, Mengapa al-Qur'an disusun dalam bagian-bagian yang disebut juz, dan mengapa jumlahnya ada 30 ? Ketiga, Apakah tanda 'ain hanya diartikan sebagai tanda berhenti membaca? Mengapa yang digunakan huruf 'ain bukan huruf lainnya? dan lain sebagainya. Lihat: Lukman Abdul Qahar Sumabrata (dkk.), Pengantar Fenomenologi al-Qur'an Dimensi Keilmuan di Balik Mushaf Usmani, 9. 
Fenomenologi al-Qur'an Dimensi Keilmuan Di Balik Mushaf Utsmani. ${ }^{5}$ Metode tersebut berupaya menafsirkan al-Qur'an dengan sudut pandang yang berbeda, yaitu menginterpretasikan al-Qur'an melalui format dan strukturnya. Penafsiran ini mengarah kepada variabel alQur'an, di mana setiap variabel memiliki makna dan saling terkait satu sama lain. ${ }^{6}$

Metode ini ditemukan oleh Lukman Abdul Qohar Sumabrata melalui pergulatan intelektual dan spiritual selama kurang lebih 20 tahun. Proses kreatif ini terjadi setelah ia berkali-kali berhasil menamatkan membaca al-Qur'an. Seluruh anggota tubuhnya berbicara secara simbolik melalui gerakan-gerakan tertentu dan menuntut diberi pemaknaan. ${ }^{7}$ Yang pada akhirnya ia menemukan sebuah metode penafsiran baru dengan memperhatikan aspek-aspek mikrokosmis di dalam diri manusia dan makrokosmis di dalam alam semesta ini.

Dalam perkembangannya, kajian tafsir fenomenologi simbolik ini merupakan kajian yang kontroversial bagi kalangan akademik. Kajian ini masih seringkali dipertanyakan tentang validitasnya dalam disiplin keilmuan tafsir al-Qur'an. Bagi penulis, titik perbedaan antara tafsir fenomenologi simbolik dan kajian tafsir konvensional ini berangkat dari perbedaan cara pandang mereka tentang makna esensi al-Qur'an. Di samping itu, upaya penafsiran yang dilakukan oleh Lukman A.Q. Sumabrata berangkat dari pemahaman mereka bahwa letak kewahyuan al-Qur'an yang paling dalam adalah terletak pada unsurunsur simbolik bukan pada bahasa verbal. Hal inilah yang menyebabkan kajian ini menjadi kajian kontroversial di kalangan para akademisi.

Tawaran metodologi yang ditawarkan oleh Lukman A.Q. Sumabrata (dkk.) ini terbuka untuk didiskusikan. Sisi metodologi yang berbeda dengan pemahaman umum, mulai dari proses kreatif, asumsi dasar yang dipakai, penggunaan standar mushaf Usmani versi mereka, hasil-hasil kreatif, sampai klaimnya sebagai sebuah metode orisinil, yang

${ }^{5}$ Islah Gusmian, Khazanah Tafsir Indonesia Dari Hermeneutik Hingga Ideologi (Jakarta Selatan: Teraju, 2003), 49-50.

'Ziyad Ul-Haq At-Tubany, Srtuktur Matematika al-Qur'an (Surakarta: Rahma Media Pustaka, 2009), 51.

${ }^{7}$ Lukman Abdul Qahar Sumabrata (dkk.), Pengantar Fenomenologi al-Qur'an Dimensi Keilmuan di Balik Mushaf Usmani (Jakarta: Grafikatama Jaya, 1991), 43.

TAJDID vol. XVI No. 1, Januari - Juli 2017 |89 
proses memperolehnya atas dasar mistis-supranatural-metafisis. ${ }^{8}$ Oleh karena itu, penelitian tentang bagaimana nuansa mistis yang terkandung dalam kajian fenomenologi al-Qur'an ini dan bagaimana posisi tafsir mistis fenomenologi simbolik dalam kerangka tafsir konvensional perlu dilakukan. Dalam artikel ini, penulis menggunakan pendekatan komparatif. Pendekatan komparatif dimaksudkan sebagai usaha mengetahui posisi tafsir fenomenologi simbolik ini dalam kerangka tafsir konvensional.

\section{Nuansa Mistis dalam Tafsir Fenomenologi Simbolik al- Qur'an}

Tafsir fenomenologi simbolik ${ }^{9}$ yang dilakukan oleh Lukman A.Q. Sumabrata mengacu pada pengalaman spiritual. Sebagaimana disebutkan dalam buku Pengantar Fenomenologi al-Qur'an, metode ini ditemukan bukan melalui proses alih ilmu dengan membaca referensi. Penulisnya menemukannya melalui kegiatan dzikir dan kegiatan mistis yang supranatural secara metafisik yang dialami sendiri oleh Lukman Abdul Qahar Sumabrata. ${ }^{10}$ Apabila metode tafsir fenomenologi simbolik al-Qur'an yang diusung oleh Lukman serat dengan unsurunsur mistisisme. Lukman sendiri sebagai penemu metode ini banyak berkecimpung dalam dunia spiritual. Bahkan dalam bukunya tersebut dikatakan bahwa ia telah melalui pergulatan intelektual dan spiritual selama 20 tahun. Ia menemukan makna-makna baru yang konsisten dan unik dalam susunan al-Qur'an yang berupa unsur-unsur simbolik

${ }^{8}$ Indal Abror, "Metodologi Fenomenologi Simbolik dalam Menafsirkan alQur'ān” Jurnal Studi Ilmu-ilmu al-Qur'an dan Hadits, Vol 1, no. 1, 2000, 11.

${ }^{9}$ Edmund Husserl mengartikan istilah fenomenologi sebagai studi tentang bagaimana orang mengalami dan menggambarkan tentang sesuatu. Menurut Husserl, kita hanya dapat mengetahui sesuatu karena sesuatu itu dialami. Sehingga hal yang penting untuk dilakukan adalah apa yang manusia alami dan bagaimana mereka memaknai serta menafsirkan pengalaman tersebut. Di antara contoh fenomena dalam kehidupan sehari-hari adalah fenomena mudik lebaran, games dan entertainment, menyukai barang impor, kawin-cerai kaum selebritis, dan lain sebagainya. Lihat: Conny R. Semiawan, Metode Penelitian Kualitatif: Jenis, Karakteristik dan Keunggulannya (Jakarta: Grasindo, 2010), 82-83. Dengan demikian, maka pengalaman spiritual adalah fenomena yang terjadi. Dalam hal ini, Lukman berusaha memberikan arti yang lebih dari proses pengalaman spiritual yang ia alami. Inilah mengapa ia menamakan metode penafsirannya sebagai bagian dari metode fenomenologi.

${ }^{10}$ Lukman Abdul Qahar Sumabrata (dkk.), Pengantar Fenomenologi al-Qur'an Dimensi Keilmuan di Balik Mushaf Usmani (Jakarta: Grafikatama Jaya, 1991), 9. 
seperti huruf, juz, surat, maupun ayat. ${ }^{11}$ Dengan demikian, dapat dikatakan bahwa hal ini menggambarkan hubungan antara objek penafsiran dan subjek penafsiran. Format dan struktur al-Qur'an sebagai objek penafsiran ditafsirkan dengan pengalaman spiritual yang dialami oleh Lukman A.Q. Sumabrata selaku subjek penafsiran. ${ }^{12}$

Metode yang ditawarkan oleh Lukman A.Q. Sumabrata ini mengandung enam teori yang semuanya sangat serat dengan nuansa mistis.

\section{Teori Huruf 13}

Menurut Lukman, huruf merupakan sebuah "penemuan" yang dicapai melalui suatu pergulatan intelektual, bahkan spiritual, maka mustahil huruf Hijaiyyah yang memiliki variasi bentuk dan karakter yang beragam itu tidak memiliki makna filosofis dan keilmuan. ${ }^{14}$ Lukman juga berpendapat bahwa setiap huruf dalam al-Qur'an mempunyai peran kunci sebagai pembuka keilmuan al-Qur'an. Setiap huruf yang terdapat dalam al-Qur'an memiliki makna tertentu dan dasar rasionalitas yang dapat dipakai secara ilmiah. ${ }^{15}$ Misalnya, huruf alif berarti otak, huruf $b a^{\prime}$ berarti mata, huruf $t a^{\prime}$ berarti THT (termasuk mulut), huruf $t s a^{\prime}$ berarti tulang, Jim berarti tangan, $b a^{\prime}$

${ }^{11}$ Lukman Abdul Qahar Sumabrata (dkk.), Pengantar Fenomenologi al-Qur'an,

${ }^{12}$ Lukman melandaskan kajiannya ini pada mushaf al-Qur'an yang dicetak oleh PT Gita Karya terbitan tahun 1982 dengan surat tanda tashih no. P.III/166/B-II/\&20/80 tertanggal 13 Ramadhan $1402 \mathrm{H}$ atau 5 Juli 1982. AlQur'an ini dicetak dengan ukuran $25 \times 36 \mathrm{~cm}$ dan 18 baris penulisan pada setiap halamannya. Akan tetapi, ada beberapa pengecualian yang terjadi pada dua halaman pertama, yaitu halaman kedua yang mengandung surat al-Fātihah yang terdiri dari tujuh ayat dan halaman ketiga yang mengandung surat al-Baqarah yang terdiri dari empat ayat. Kedua halaman ini hanya hanya terdiri dari enam baris penulisan. Pengecualian lainnya juga terjadi pada halaman ke- 485 sebagai halaman terakhir yang hanya terdiri dari 15 baris. Lihat: Iskandar Agung Sumabrata, Pesan-pesan Numerik al-Qur'an (Jakarta Selatan: Republika, 2006), 5.

${ }_{13}$ Metode yang dilakukan Lukman dalam mengungkap makna simbolik di balik ayat-ayat yang hanya terdiri dari beberapa huruf saja atau dalam istilah tafsir konvensional disebut sebagai al-ahrüf al-muqatta'ah, yaitu dengan cara menafsirkan masing-masing huruf berdasarkan makna simbolik yang telah diketahui dalam teori huruf.

${ }^{14}$ Lukman Abdul Qohar, (dkk.), Pengantar Fenomenologi al-Qur'an Dimensi Keilmuan di balik. Mushaf Usmani, 66.

${ }^{15}$ Lukman Abdul Qohar, (dkk.), Pengantar Fenomenologi al-Qur'an Dimensi Keilmuan di balik Mushaf Usmani, 70.

TAJDID Vol. XVI No. 1, Januari - Juli $2017 \mid 91$ 
berarti sandi, kha' berarti paru-paru, dal berarti darah atau jantung dan seterusnya. ${ }^{16}$

Bagi sebagian orang, pemaknaan secara simbolik terhadap hurufhuruf al-Qur'an di atas masih tabu. Mereka menganggap itu sebagai kejanggalan karena huruf-huruf tersebut dapat bermakna demikian. Akan tetapi, bagi sosok Lukman A.Q. Soemabrata yang berperan sebagai pencetus metode penafsiran ini berkata bahwa pemaknaan abjad yang diperoleh melalui jalan mistik, intuitif, ${ }^{17}$ dan inspiatif 18 itu telah diuji-cobakan dalam realitas obyektif. Apabila makna tersebut dideduksikan ke dalam realitas empirik atau manusia, maka akan jelas makna tersebut memiliki dasar obyektif. Misalnya, huruf "ق" yang berada di urutan ke-21 dalam deretan huruf hijaiyyah, arti simboliknya adalah kepala atau analisis ulang. Apabila pemaknaan huruf tersebut dihubungkan dengan realita empirik atau seseorang yang berjuz $21,{ }^{19}$ maka dapat dipastikan bahwa orang tersebut memiliki kelemahan laten pada kepala dan memiliki kecakapan dalam analisis ulang yang lebih tinggi. ${ }^{20}$

${ }^{16}$ Lihat: Lukman Abdul Qahar Sumabrata (dkk.), Pengantar Fenomenologi alQur'an Dimensi Keilmuan di Balik. Mushaf Utsmani, hlm. 83. Mengenai teori huruf ini juga telah dibahas cukup lengkap dalam Nunung Lasmana dan Ahmad Suhendra, "Tafsir Fenomenologi Simbolik al-Qur'an" dalam Jurnal Empirisma, Vol. 24, No. 1 Januari 2015, 18.

${ }^{17}$ Intuisi atau dalam pemikiran Islam biasa disebut hati (qalb) merupakan sarana untuk mendapatkan pengetahuan secara langsung. Intuisi bertumpu pada pengalaman-pengalaman batin spiritual yang disebut pengalaman eksistensial. Metode untuk mendapatkan pengetahuan bersifat langsung terhadap objek metafisik biasa dinamakan metode intuitif ('irfani). Adapun produk intuitif dinamakan sebagai pengetahuan intuitif. Pengetahuan ini bukan diperoleh melalui penginderaan dan bukan pula penalaran rasional melainkan melalui pengalaman langsung. Lihat: Muniron, Epistemologi Ikhwan as-Shafa (Yogyakarta: Pustaka Pelajar, 2011), 304-306.

${ }^{18}$ Secara bahasa, inspirasi berarti pengaruh dari dalam yang membangkitkan kreatif dan penarikan nafas. Lihat: Pius A. Partanto \& M. Dahlan al-Barry, Kamus Ilmiah Populer (Surabaya: Arkola, t.t), 260. Istilah ini biasa kita dengar oleh orang-orang yang mencari suasana baru atau suasana yang tenang demi memperoleh inspirasi demi sebuah tulisannya.

${ }^{19}$ Untuk mengetahui apakah seseorang ber-juz sekian hanya dapat dilakukan melalu jalan spiritual sebagaimana yang dilakukan Lukman sehingga sulit untuk dijangkau oleh nalar manusia pada umumnya.

${ }^{20}$ Lukman Abdul Qahar Sumabrata (dkk.), Pengantar Fenomenologi al-Qur'an Dimensi Keilmuan di Balik. Mushaf Usmani, 85. 


\section{Teori Angka}

Angka dalam al-Qur'an memiliki kebenaran tersendiri. Angka dalam kaitan nomor surat, ayat maupun juz merupakan petunjuk adanya keterkaitan antara berbagai unsur simbolik. Hubungan antara ayat dengan ayat, ayat dengan surat, surat dengan surat, direfleksikkan dengan angka. Angka juga menjadi simbol dan representasi dimensi ruang dan waktu dalam alam semesta. ${ }^{21}$ Bagi pengarang, susunan dan urutan nama surat tidaklah bersifat kebetulan atau asal-asalan. Angka dalam al-Qur'an memiliki paradigma ganda. Suatu angka dapat bermakna luas. Nomor surat, jumlah ayat, nomor abjad akan merujuk kepada suatu benda tertentu yang ada dalam diri manusia konsepsi tertentu. 22

Misalnya, jumlah surat dalam al-Qur'an adalah 114. Apabila angka ini "dimampatkan" atau dijumlahkan, maka menjadi 6. Dan angka 6 sama dengan huruf $h a$ ' yang berarti sendi, syaraf, hukum, dan kausalitas. Dengan demikian, al-Qur'an adalah simbol kausalitas atau sunnatullah. Hubungan kausalitas dan sistemik antara satu unsur kosmik dengan lainnya itulah yang disandikan sebagai huruf $h a^{\prime}$ atau angka $114 .{ }^{23}$

\section{Teori Ayat}

Tafsir fenomenologi simbolik dalam metode ini tidak bermakna menafsirkan ayat sebagaimana yang dilakukan oleh para mufassir konvensional. Teori ayat yang dimaksud adalah menafsirkan makna simbolik di balik jumlah seluruh ayat yang terdapat dalam al-Qur'an dan ayat-ayat al-Qur'an yang hanya terdiri dari beberapa huruf saja. Dalam hal ini, Lukman memilih pendapat yang menyatakan bahwa jumlah ayat dalam al-Qur'an adalah 6236. Untuk mengetahui makna simbolik di balik angka tersebut, maka angka 6236 harus dimampatkan terlebih dahulu. Dengan kata lain, angka 6236 dapat menjadi $6+2+3+6=17$, dan angka 17 dapat menjadi $1+7=8$. Setelah dimampatkan atau dipadatkan seperti itu, maka kita dapat mengetahui makna simbolik di balik jumlah ayat 6236 dalam alQur'an, yaitu:

${ }^{21}$ Lukman Abdul Qahar Sumabrata (dkk.), Pengantar Fenomenologi al-Qur'an Dimensi Keilmuan di Balik Mushaf Usmani, 53.

${ }^{22}$ Lukman Abdul Qahar Sumabrata (dkk.), Pengantar Fenomenologi al-Qur'an Dimensi Keilmuan di Balik Mushaf Usmani, 85.

${ }^{23}$ Lukman Abdul Qahar Sumabrata (dkk.), Pengantar Fenomenologi al-Qur'an Dimensi Keilmuan di Balik Mushaf Usmani, 87.

TAJDID Vol. XVI No. 1, Januari - Juli 2017|93 
a) Angka 17 dapat dikaitkan dengan jumlah raka'at shalat lima waktu, itu berarti semua aktivitas ritual dalam Islam seperti shalat memiliki relevansi simbolik dengan struktur dan susunan al-Qur'an.

b) Angka 8 merujuk pada 8 macam gerak dalam salat, niat, takbir, dan ruku', i'tidal, sujud pertama, duduk di antara dua sujud, sujud kedua dan tahiyat.

c) Angka 8 dapat merujuk juga dalam putaran waktu salat dalam 24 jam yaitu; 'asar maghrib, isya, sunnah lail, sunnah fajar, subuh, sunnah duha dan zhuhur.

d) Angka 8 adalah padanan abjad ( () yang berarti darah atau jantung. Sifat hakiki darah adalah sirkulatif sebagaimana kehidupan.

e) Angka 8 juga merujuk kepada 8 kelompok surat dalam susunan al-Qur'an yang terbagi oleh juz.

\section{Teori Surat}

Nama-nama surat dalam al-Qur'an secara harfiah memiliki arti yang sangat sederhana. Misalnya, surat al-Baqarab yang berarti sapi betina, an-Naml yang berarti semut, al-Ankabüt yang berarti laba-laba, dan lain sebagainya. Penamaan surat-surat tersebut pastilah memiliki maksud dan makna yang tersembunyi sebagai pesan spiritual yang harus dipikirkan dan ditelaah oleh manusia._ ${ }^{24}$ Misalnya, surat alAn'ām yang berarti binatang ternak maka ini mengindikasikan bahwa dalam diri manusia terdapat nafsu ataupun insting kebinatangan. ${ }^{25}$

5. Teori Juz 26

Apa makna di balik pembagian al-Qur'an menjadi 30 juz dan apa makna keilmuan di balik susunan juz dalam al-Qur'an? Maksud pengarang dari pertanyaan tersebut bukanlah mengarah kepada alasan

\footnotetext{
${ }^{24}$ Lukman Abdul Qahar Sumabrata (dkk.), Pengantar Fenomenologi al-Qur'an Dimensi Keilmuan di Balik Mushaf Usmani, 109.

${ }^{25}$ Lukman Abdul Qahar Sumabrata (dkk.), Pengantar Fenomenologi al-Qur'an Dimensi Keilmuan di Balik. Mushaf Usmani, 110.

${ }^{26}$ Dalam hal ini, Lukman A.Q. Sumabrata membagi keunikan juz ke dalam tiga bagian, yaitu: pertama, halaman. Setiap juz rata-rata terdiri dari 8 lembar atau 16 halaman. Dengan demikian, ada korelasi secara simbolik antara jumlah ayat dalam juz dan jumlah halaman atau lembar. Kedua, pembagian juz didasarkan atas surat. Artinya, dalam setiap juz terdapat beberapa unsur, yaitu ayat, surat, dan tanda 'ain. Ketiga, pembagian juz didasarkan atas jumlah ayat bukan jumlah surat. Lihat: Lukman Abdul Qahar Sumabrata (dkk.), Pengantar Fenomenologi alQur'an Dimensi Keilmuan di Balik Mushaf Usmani, hlm. 123.
} 
historis karena pengarang sendiri menyadari bahwa pembagian alQur'an ke dalam 30 juz tersebut bertujuan untuk memudahkan dalam membaca al-Qur'an. Akan tetapi, bagi pengarang, ini bukanlah jawaban yang tepat untuk membuktikan bahwa al-Qur'an adalah sumber ilmu pengetahuan. Artinya, pembagian tersebut pasti memiliki makna simbolik yang dapat mengungkap realitas obyektif dalam dunia empiris. ${ }^{27}$ Fungsi juz dalam al-Qur'an tersebut juga tertuang dalam makna simbolik dari istilah juz itu sendiri. Istilah juz apabila diuraikan dalam rangkaian huruf dan angka maka akan menjadi:

$(s)+(j)+(ج)$

$$
(29)+(11)+(5)=45
$$

Apabila angka 45 dihubungkan dengan nomor surat maka ia adalah (الجاثية) orang yang bertekuk lutut. Makna metapor orang yang bertekuk lutut adalah yang mendapat tugas dan tanggung jawab keilmuan al-Qur'an yang dapat diterima setiap manusia. ${ }^{28}$ Makna inilah yang mengisyaratkan bahwa juz itu berfungsi untuk mengungkapkan pesan-pesan keilmuan yang terkandung dalam alQur'an. Menurut mereka, setiap juz menggambarkan karakter manusia. Karena itu setiap manusia, apapun agama dan asal-usul bangsa serta etnisnya, memiliki juz dalam al-Qur'an. Jadi, setiap orang yang membaca juznya akan memperoleh pengaruh langsung dari bacaannya. ${ }^{29}$

Pada bagian ini, pengarang memberikan contoh penafsiran berikut ini; huruf Hijaiyyah ke-21 adalah $q \bar{a} f(ق)$ yang melambangkan karakter dasar kepala atau pemikiran ulang. Maka, seorang yang berjuz 21 memiliki karakter yang terkandung dalam huruf $q \bar{a} f$ (ق). Juz 21 mengandung beberapa surat yang melambangkan karakter manusia yang berjuz 21, yaitu surat al-Ankabūt (laba-laba), ar-Rūm (Romawi), Lukmān, as-Sajdah, dan surat al-Ahzāb. ${ }^{30}$ Namun, untuk mengetahui juz seseorang pun melalui jalan supranatural.

\footnotetext{
${ }^{27}$ Baca: Lukman Abdul Qahar Sumabrata (dkk.), Pengantar Fenomenologi alQur'an Dimensi Keilmuan di Balik. Mushaf Usmani, 122-123.

${ }^{28}$ Lukman Abdul Qahar Sumabrata (dkk.), Pengantar Fenomenologi al-Qur'an Dimensi Keilmuan di Balik Mushaf Usmani, 135.

${ }^{29}$ Lukman Saksono \& Anharudin, Pengantar Psikologi al-Qur'an Dimensi Keilmuan di Balik. Mushaf Usmani (Jakarta: Grafikatama Jaya, 1992), 11

${ }^{30}$ Lihat: Lukman Abdul Qahar Sumabrata (dkk.), Pengantar Fenomenologi alQur'an Dimensi Keilmuan di Balik Mushaf Usmani, 127.
}

TAJDID vol. XVI No. 1, Januari - Juli $2017 \mid 95$ 


\section{Teori 'Ain}

Huruf 'ain yang dalam urutan Hijaiyyah berada di posisi ke-18 ini dapat dipakai untuk mendeteksi kelemahan dan kelebihan fisik setiap orang dalam konteks juznya. Angka 18 ini memiliki hubungan simbolik dengan baris pada setiap halaman al-Qur'an dalam Mushaf Usmani yang jumlahnya juga 18. Itulah mengapa tanda berhenti membaca atau rukuk menggunakan huruf 'ain, bukan huruf lainnya. Hal ini dikarenakan huruf (ع) bila dibunyikan akan menjadi (عين) yang berarti mata. Makna ini mengindikasikan bahwa pada posisi ayat tertentu kita dianjurkan untuk mengamati ayat tersebut dengan mata dan bila perlu berhenti sejenak. ${ }^{31}$

\section{Relevansi Antara Tafsir Fenomenologi Simbolik dan Tafsir 'Isyari}

Pada bagian ini, penulis ingin menguraikan kemiripan antara tafsir fenomenologi simbolik dan tafsir isyari ${ }^{32}$ dari aspek origin (sumber pengetahuan) yang keduanya bertumpu pada kekuatan spiritual. Penafsiran model ini biasa dilakukan oleh para sufi dengan melakukan latihan ruhani sehingga nampak baginya isyarat-isyarat suci yang terdapat di balik ungkapan-ungkapan dhahir al-Qur'an. ${ }^{33}$ Bagi mereka, tingkat spiritualitas yang mereka lakukan dengan cara menahan diri dari berbagai kepentingan duniawi akan menyampaikannya ke suatu tingkatan yang dapat membukakan mata hatinya dalam menyingkap rahasia-rahasia di balik ayat-ayat alQur'an. ${ }^{34}$ Nampaknya tepat ketika Paul Nywia mengumpamakan tafsir-tafsir sufistik seperti "permainan cermin-cermin antara sisi batin tasawuf dan sisi batin kitab suci". ${ }^{35}$ Dengan kata lain, para sufi

${ }^{31}$ Lukman Abdul Qahar Sumabrata (dkk.), Pengantar Fenomenologi al-Qur'an Dimensi Keilmuan di Balik Mushaf Usmani, 143.

${ }^{32}$ Tafsir isyari adalah pentakwilan terhadap ayat-ayat al-Qur'an yang tidak sesuai dengan makna dzahirnya untuk mengungkap isyarat-isyarat yang tersembunyi dan jelas bagi ablul 'ilmi dan ablus suluk berdasarkan syarat-syarat tertentu. Lihat: Khālid Abdurrahmān al-Akk, Ușul al-Tafsir wa Qawā'iduhu, (Beirut: Dār al-Nafá'is, 1986), 205 dan Muhammad Husein al-Dhahabi, Tafsir wal Mufassirūn Jilid 2 (Kairo: Maktabah wa Hibbat, t.th.), 261.

${ }^{33}$ Manna' Khalil al-Qațāan, Mabāhis Fì 'Ulūm al-Qur'ān (t.tp.: Mansyurāt al'Așri al-Hadith, 1990), 357.

${ }^{34}$ Manna' Khalil al-Qațtān, Mabāhiṣ Fì 'Ulūm al-Qur'ān, 357.

${ }^{35} \mathrm{P}$. Nwyia, "Un cas d'exégèse soufie: l'histoire de Joseph" in S.H. Nasr, Mélanges Henri Corbin, Tehran: Kitāb furūṣ̂̀-yi Ṭāhūrỉ dikutip oleh Annebel 
menggunakan analisis mistis yang dilandaskan oleh pengalaman spiritualnya untuk menggali pesan-pesan simbolik yang terpendam dalam kitab suci al-Qur'an.

Produk dari pengalaman spiritualnya terlihat pada penemuanpenemuannya tentang makna simbolik dari huruf-huruf Hijaiyyah dan kriteria masing-masing juz yang melekat pada setiap jiwa manusia. Pemaknaan yang ia ungkapkan sangat bersifat subjektif dan sulit untuk dipertanggungjawabkan secara logika. Kekuatan subjektif inilah yang biasa disebut dengan sesuatu yang transendental. ${ }^{36}$ Terkait dengan pembahasan ini, Kuntowijoyo menjelaskan lebih dalam tentang struktur transendental. Ia menjelaskan bahwa struktur transendental dapat dijadikan referensi untuk menafsirkan realita. Ia juga menegaskan bahwa yang dimaksud di sini adalah pengakuan adanya ide yang murni dan sumbernya berada di luar diri manusia; suatu konstruk tentang suatu nilai-nilai yang berdiri sendiri dan bersifat transendental. ${ }^{37}$ Pernyataan yang diungkapkan oleh Kuntowijoyo tentang struktur transendental cukup tepat sebagai gambaran sumber pengetahuan yang digunakan oleh Lukman dalam buku Pengantar Fenomenologi al-Qur'an. Hal ini sebagaimana dikatakan dalam bagian pengantar buku ini bahwa metode yang ditawarkan oleh Lukman adalah metode yang benar-benar baru yang diperoleh melalui kegiatan dzikir dan kegiatan mistis yang supranatural serta metafisik. 38 Dengan kata lain, ada sumber pengetahuan yang berada di luar diri manusia dalam tafsir fenomenologi simbolik ini.

Dalam tradisi sufi, muncul berberapa mufassir dengan corak tafsir isyari, di antaranya adalah At-Tustārī (w. $283 \mathrm{H}$ ) dengan kitabnya Tafsir al-Qur'ān al-'Azīm, Abu Abdurrahman as-Sulami $(1.330 \mathrm{H})$ dengan kitabnya Haqā'iq at-Tafsìi, al-Qushayrì $(374 \mathrm{H}$ -

Keeler, "Tafsir Sufistik Sebagai Cermin: al-Qushairy Sang Mursyid dalam Karyanya Laṭā'iful Ishārāt”, Jurnal Studi al-Qur'an, Vol. II, No. I, 2007, 171.

${ }^{36}$ Kata "transendental" diambil dari kata kerja transcend yang berasal dari bahasa Latin transcendere yang artinya memanjat di/ke atas. Dari lima arti dalam Webster's New International Dictionary yang dekat dengan keperluan kita ialah transcendental dengan makna "abstrak, metafisis" dan "melampaui". Lihat: Kuntowijoyo, Islam Sebagai Ilmu: Epistemologi, Metolodogi, dan Etika (Yogyakarta: Tiara Wacana, 2007), 34.

${ }^{37}$ Kuntowijoyo, Paradigma Islam: Interpretasi Untuk Aksi (Bandung: Mizan Publika, 2008), 555.

${ }^{38}$ Lukman Abdul Qahar Sumabrata (dkk.), Pengantar Fenomenologi al-Qur'an Dimensi Keilmuan di Balik Mushaf Usmani, 8-9.

TAJDID vol. XVI No. 1, Januari - Juli $2017 \mid 97$ 
$465 \mathrm{H})$ dengan kitabnya Lațâ'if al-Ishärät, ash-Shayrazi dengan kitabnya Arāis al-Bayān Fì Haqā'iq al-Qur'ān, Najm al-Dīn Dayyah $(653 \mathrm{H})$ dengan kitabnya yang berjudul al-Ta'wilät alNajmiyah, al-Niẓām al-A'rāj al-Qummì al-Naysāburì (w. $728 \mathrm{H}$ ) dengan kitabnya Gharā'ib al-Qur'ān wa Raghà'ib al-Furqān, Ismā‘il al-Haqqi ibn Muștafạ al-Istanbūli (w. $1127 \mathrm{H}$ ) dengan kitabnya Rüh al-Bayān fî̀ al-Tafsìr al-Qur'ān, al-Alūsì (1217-1270 H) dengan kitabnya $R \bar{u} h$ al-Ma 'ānì, dan lain sebagainya. ${ }^{39}$

\section{Kerangka Teori yang Bertumpu pada Dhahir-Bathin}

Apabila dicermati lebih teliti, penafsiran yang dilakukan oleh Lukman berupaya mengungkap makna batin yang terkandung di balik fenomena-fenomena al-Qur'an. Hal inilah yang menyebabkan upaya penafsirannya sulit dijangkau berdasarkan nalar rasio karena sifatnya sangat "arbitrer". Misalnya, huruf $h a$ ' dituliskan dengan angka 6 yang berarti sendi, kausalitas, hukum, ataupun syaraf. Sedangkan huruf mim dituliskan dengan angka 24 yang apabila dimampatkan atau dijumlahkan sama dengan 6. Adapun makna simbolik huruf mim adalah mata rantai kejadian atau peristiwa. Dikatakan "arbitrer" karena apabila diukur berdasarkan nalar rasional, penjelasan seperti ini sangat tidak masuk akal. Di samping itu, tidak ada kejelasan bagaimana proses simbolisasi antara huruf $b a^{\prime}$ dan sendi, huruf mim dan peristiwa. Begitu juga dengan format juz, bagaimana ia dapat mengetahui bahwa seseorang berjuz sekian dan memiliki karakter tertentu.

Hal ini serupa dengan tafsir isyari yang menjadikan lahir-batin sebagai konsep yang dipergunakan untuk melandasi pemikirannya dalam menafsirkan al-Qur'an khususnya dan melihat dunia pada umumnya. Pola sistem berpikir mereka berangkat dari hal yang dzahir menuju kepada hal yang batin. Bagi mereka, batin adalah sumber pengetahuan sedangkan dzahir teks adalah penyinarnya. Rujukan yang mereka gunakan adalah pernyataan yang selalu dinisbatkan kepada Ali Ibn Abi Țalib bahwa setiap ayat al-Qur'an memiliki empat makna, yaitu zahir, batin, had, dan matla'. Al-Ghazāli menegaskan bahwa selain makna zahir, al-Qur'an memiliki makna batin. Abdullāh (alMuhāsibi) dan Ibn al-'Arabi memberitahukan penjelasan pernyataan tersebut bahwa yang dimaksud dengan makna zahir adalah makna

${ }^{39}$ Lihat perkembangan tafsir isyari dalam Muhammad Husein al-Dhahabi, Tafsìr wal Mufassirūn, 281-295.

98 | TAJDID vol. XVI No. 1, Januari - Juli 2017 
yang sesuai dengan bacaan, sedangkan makna batin adalah takwilnya. ${ }^{40}$

Sebagaimana tafsir fenomenologi simbolik yang dipaparkan oleh Lukman A.Q. Sumabrata, tafsir isyari yang dipaparkan oleh kaum sufi seringkali bersifat arbitrer. Misalnya, penafsiran at-Tustari tentang makna basmalah dalam surat al-Fātihah ayat 1 :
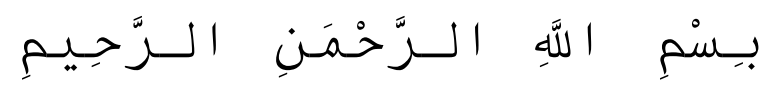

“Huruf ba' (ب) dalam lafadz bismi (بِ (بنسْ) bermakna keindahan Allah, huruf $\sin (\omega)$ bermakna keagungan Allah, dan huruf mim (م ) bermakna kemuliaan Allah 'Azæa wa Jalla. Adapun lafadz Allah (الِّa ) menunjukkan nama yang paling Agung di antara nama-nama lainnnya dan di antara huruf alif dan lām tersimpan sebuah huruf yang hanya dapat diketahui oleh orang-orang yang mensucikan dirinya. Dalam pandangannya, Allah menghilangkan keputus-asaan yang dialami orang-orang mu'min dengan menyebut kedua lafadz ar-Rahmān dan ar-Rahim."41

Penafsiran dengan model seperti itu juga dapat dilihat dalam kitab Lat à'if al-Ishärāt karya al-Qushayrī (374 H - 465 H). Dalam kajian tafsir al-Qushayri, penulis mengambil contoh al-ahrüf almuqatta'ah sebagai salah satu objek yang sering kali dijadikan sorotan penafsiran oleh para mufassir esoterik maupun kaum orientalis, salah satunya adalah alif läm mīm (الم) dalam Q.S. al-Baqarah : 1. Mengenai ayat tersebut, al-Qushayri banyak mengungkapkan pendapatpendapat para ulama tentang makna dibalik huruf-huruf tersebut. Di antaranya adalah pendapat suatu kaum yang menyatakan bahwa huruf alif (I) melambangkan makna Allah, huruf lām (J) berarti al-Lațîf atau Maha Lembut, dan huruf mìm (ə) berarti al-Majīd wa al-Mulk atau Maha Mulia dan Maha Kuasa. Setelah ia mengungkapkan beberapa penafsiran yang mengisyaratkan makna yang sama, ia menganalisis makna huruf alif yang selalu disimbolkan dengan nama Allah. Menurutnya, alif adalah satu-satunya huruf Hijaiyyah yang selalu

${ }^{40}$ Al-Jābiri, Bunyah al-'Aql al-'Arab dalam Asep Nurdin "Karakteristik Tafsir Sufi: Telaah Atas Metodologi Penafsiran al-Qur'an Ulama Sufi”, Jurnal Studi al-Qur'an dan Hadith Vol. 3, No. 2 Januari 2003, 154.

${ }^{41}$ Abū Muhammad Sahl Ibn Yūnus Ibn Rāei' al-Tustarī, Tafsìr al-Tustarī, Jilid 1, hlm. 1 dalam CD ROM Maktabah Syamilah. Lihat juga al-Tustari, "Tafsir alTustarī” dalam http://www.altafsir.com, diakses pada 3 November 2012.

TAJDID Vol. XVI No. 1, Januari - Juli 2017 |99 
sendiri karena tidak dapat bersambung dengan huruf lain, tetapi huruf-huruf lainnya dapat bersambung kepadanya kecuali sebagian kecil dari huruf Hijaiyyah. Hal ini mengisyaratkan bahwa seluruh makhluk butuh bersandar kepada-Nya. ${ }^{42}$

Simbolisme yang dilakukan oleh kaum sufi di atas terkait dengan susunan huruf atau kata-kata dalam al-Qur'an. Para penafsir tersebut biasanya memfokuskan kajiannya pada al-ahrüf al-muqatta'ah. Dalam diskursus ulumul Qur'an, kajian ini menjadi salah satu materi yang mengundang banyak perhatian para sarjana muslim dan bahkan para orientalis. Dalam periode klasik, keberadaan al-ahrüf almuqatta'ah telah banyak dikaji dan memunculkan banyak versi tentang maksud yang terkandung di dalamnya. Banyak para ulama yang menggolongkan al-ahrüf al-muqatta'ah ke dalam bagian dari ayat-ayat mutashābihāt. Di antaranya adalah as-Suyūti, pengarang kitab al-Itqān Fì 'Ulüm al-Qur'ān yang meyakini bahwa huruf-huruf tersebut merupakan misteri dari kitab suci al-Qur'an dan yang mengetahui makna dan maksudnya hanyalah Tuhan. Hal ini karena ada beberapa riwayat yang menyatakan bahwa huruf tersebut adalah bagian dari nama-nama Allah SWT.43 Paradigma ini akhirnya dipegang oleh mayoritas mufassir ketika menafsirkan al-Qur'an, sehingga ketika berhadapan dengan huruf-huruf tersebut mereka merendahkan diri seraya berkata "الله أعلم بمرده".

Penafsiran teks dengan mengungkap makna batin ternyata bukan metode penafsiran pertama yang lahir dari kalangan Islam. Sebelum Islam datang tepatnya pada tahun 300 sebelum Masehi, seorang ilmuwan Barat telah mengembangkan sebuah metodologi penafsiran teks menjadi interpretasi alegoris. Metode ini dikembangkan lebih lanjut oleh Philo of Alexandria (20 SM-50 SM), seorang Yahudi yang

\footnotetext{
${ }^{42}$ Penjelasan ini dikutip dari ibarat yang terdapat dalam "Abd al-Karīm Ibn Hawāzin Ibn 'Abd al-Malik al-Qushayrī," Lațā'if al-Ishārāt”, Jilid 1, hlm. 9 dalam CD ROM. Maktabah Shāmilah yang berbunyi:

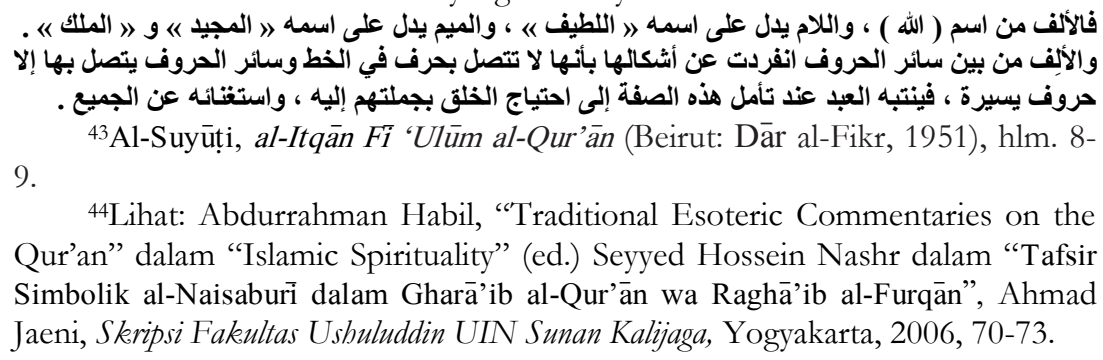

100 | TAJDID Vol. XVI No. 1, Januari - Juli 2017 
disebut dengan Bapak metode Alegoris. Ia mengajukan metode yang bernama typology yang menyatakan bahwa pemahaman makna spiritual teks tidak berasal dari teks itu sendiri, akan tetapi kembali pada sesuatu yang berada di luar teks. Philo menerapkan metode ini atas perjanjian lama, ia menginterpretasikan "pohon kehidupan" sebagai "takut kepada Tuhan", "pohon pengetahuan" sebagai "hikmah", "empat sungai yang mengalir di surga" sebagai "empat kebajikan pokok", "Habil" sebagai "takwa yang bersumber dari akal", "Qabil" sebagai "egoisme", dan sebagainya. 45

Bahkan, dalam tradisi Kristen metode alegoris Philo "dibaptiskan" ke dalam Kristus. Menurut Philo, apabila sesuatu dinyatakan yang kelihatannya sudah jelas, pasti ada arti yang lebih tersembunyi dalam pernyataan tersebut. Dan karena bagi Philo, sama seperti bagi setiap orang Yahudi sezamannya, kitab suci adalah karya Allah, setiap ungkapan, setiap perkataan dan setiap huruf punya arti sendiri. Sebagaimana aliran Stois, dia menemukan arti tersembunyi ini dari segi etimologis, yang seringkali dengan sangat dipaksakan, dan aritmologi. Arti dari perkataan dapat ditemukan dari sumbernya, dan bilangan-bilangan juga memiliki arti khusus. ${ }^{46}$

Eksistensi tafsir isyari yang terekam dalam ranah historis telah mengundang berbagai respon dari kalangan para ulama. Sebagian tafsir simbolik divonis sebagai tafsir yang menyeleweng karena bertentangan dengan ajaran-ajaran al-Qur'an secara umum. Hal ini disebabkan oleh beberapa faktor, yaitu: pertama, mereka khawatir dengan hanya mengambil makna simbolik, akhirnya mengabaikan makna lahiriyah. Hal ini menyebabkan mereka hanya menerima ta'wil dan meninggalkan tanzil. Kedua, pengambilan makna simbolik seringkali mengabaikan hukum-hukum bahasa Arab. Makna denotatif dari berbagai kata ditundukkan pada makna konotatif yang diperoleh seseorang dari pengalaman spiritualnya. ${ }^{47}$ Pengalaman seperti ini pada

${ }^{45}$ Saifuddin, "Hermeneutik Sufi: Menembus Makna di Balik Kata" dalam Hermenentik al-Qur'an dan Hadith (ed.) Sahiron Syamsuddin (Yogyakarta: eLSAQ Press, 2010), 53.

${ }^{46}$ Robert M. Grant dan David Tracy, Sejarah Singkat Penafsiran al-Kitab terj. Agustinus Maleakhi (Jakarta: PT BPK Gunung Mulia, 2000), 59.

${ }^{47}$ Dalam kajian bahasa Indonesia, istilah makna denotatif mengarah kepada kata yang tidak menimbulkan rasa negatif maupun positif atau bisa disebut juga dengan netral, seperti: putih, kursi, kasur, dan lain sebagainya. Sedangkan makna konotatif adalah sebuah kata yang memiliki rasa tertentu, seperti: mayat dan

TAJDID vol. XVI No. 1, Januari - Juli 2017|101 
gilirannya sangat subyektif dan irasional sehingga sulit diverifikasi. Ketiga, tafsir sufi dicurigai karena tasawuf dianggap sebagai ajaran yang menyimpang dari al-Qur'an dan Sunnah, atau lebih buruk lagi sebagai ajaran kaum musyrikin yang dimasukkan ke dalam ajaran Islam. ${ }^{48}$

Hal ini wajar mengingat secara substansial, perkembangan tasawuf 49 dalam tradisi Islam dipandang oleh sebagian kalangan memiliki kontak hubungan dengan tradisi-tradisi lain seperti tradisi Hindu-Budha, Nasrani, Persia, Yunani, dan tradisi lainnya. ${ }^{50}$ Ketika terjadi sentralisasi tasawuf dalam dunia penafsiran maka mereka menganggap adanya kemungkinan ketiga unsur di atas, yaitu penafsiran al-Qur'an, tasawuf, dan tradisi agama lain akan saling mempengaruhi satu sama lainnya. Oleh karena itu, untuk mengukur tingkat kevaliditasan sebuah tafsir sufi, para mufassir menentukan indikator-indikator tertentu sehingga dapat diketahui antara penafsiran yang bertentangan dengan syari'at Islam dan penafsiran yang sesuai dengan syari'at Islam. Indikator-indikator ini terdiri dari beberapa syarat, yaitu: pertama, tidak meniadakan makna dhahir yang terkandung dalam susunan ayat al-Qur'an. Kedua, penafsiran tersebut dikuatkan dengan adanya dalil shar'i. Ketiga, penafsiran tersebut tidak bertentangan baik secara syara' maupun akal. Keempat, harus mempertimbangkan makna dhahir terlebih dahulu dalam mengungkap rahasia-rahasia al-Qur'an. ${ }^{51} \mathrm{Hal}$ ini mengindikasikan bahwa penafsiran al-Qur'an yang diperoleh dari aktivitas spiritual seperti mujahadah, riyadah, dan latihan ruhani lainnya tidak semestinya diterima secara langsung tanpa melakukan verifikasi terlebih dahulu.

jenazah, mati dan meninggal, dan lain sebagainya. Lihat: Paulus Tukan, Mahir Berbahasa Indonesia 3 (Yudhistira Ghalia Indonesia), 19.

${ }^{48}$ Jalaluddin Rahmat, Tafsir Sufi al-Fätihah (Bandung: Rosdakarya, 1999), $\mathrm{xV}$.

${ }^{49}$ Beberapa ahli penelitian, baik di Timur maupun di Barat berpendapat bahwa tasawuf adalah paham asing yang masuk ke dalam agama Islam. Mereka mengatakan nama "Tasawuf" itu sendiri berasal dari bahasa Yunani, yaitu berasal dari kata theosophy yang berarti hikmah Illahi. Baca: Abbas Mahmud alAqqad, Filsafat Qur'an, terj. Tim Pustaka Firdaus (Jakarta: Pustaka Firdaus, 1986), 257.

${ }^{50}$ Baca lebih lanjut tentang keterpengaruhan tasawuf oleh tradisi-tradisi lain dalam Rosihon Anwar dan Mukhtar Sholihin, Ilmu Tasawuf (Bandung: Pustaka Setia, 2000 ), 29-47.

${ }^{51}$ Muhammad Husein al-Dhahabi, at-Tafsir wa al-Mufassirūn, hlm. 280. 
Inilah mengapa sebagian orang berpendapat bahwa tafsir fenomenologi simbolik yang digagas oleh Lukman digolongkan ke dalam model penafsiran isyari yang biasa dilakukan oleh kaum sufi. Hal ini dikarenakan keduanya sama-sama melakukan interpretasi simbolik yang dilandaskan dengan pengalaman spiritual. Apabila ditinjau secara generik, metode penafsiran yang dilakukan oleh Lukman AQ Sumabrata dan kawan-kawannya dapat dikatakan sebagai tafsir isyari karena keduanya sama-sama menafsirkan al-Qur'an melalui isyarat-isyarat yang diperoleh melalui pengalaman spiritual. Akan tetapi, istilah tafsir isyari telah menjadi istilah baku yang dipinjam oleh para mufassir konvensional. Model penafsiran ini mengarah kepada upaya pengungkapan makna batin yang terkandung di balik makna lahiriah ayat-ayat al-Qur'an. Pengertian ini telah disepakati oleh para ulama terkemuka seperti az-Dzahabī, Ibn Șalāh, at-Taftazānī, al-'Akk, dan lain sebagainya. ${ }^{52}$

\section{Posisi Tafsir Fenomenologi Simbolik al-Qur'an di Ranah Tafsir Konvensional}

Secara metodologis, memang sulit untuk memposisikan tafsir fenomenologi simbolik ke dalam kerangka tafsir konvensional. Apabila ditarik garis hubungannya dengan penafsiran konvensional memang metode fenomenologi simbolik al-Qur'an ini tidak hanya memiliki kemiripan dengan tafsir isyari, tetapi juga dengan tafsir 'ilmi. Letak kemiripan di antara keduanya karena setiap pemaknaan yang dihasilkan selalu terikat pada aspek macrocosmis dan microcosmos. Lukman A.Q. Sumabrata menjelaskan bahwa metode penafsiran yang ia tawarkan berkaitan dengan aspek kongkrit kehidupan manusia. Misalnya, setiap simbol dalam al-Qur'an merupakan gambaran riil setiap manusia. Keseluruan fenomena simbolik dalam al-Qur'an baik huruf, angka, surat maupun juz secara logis-empiris dapat dibuktikan memiliki realitas obyektif, baik berupa fenomena budaya, manusia, maupun alam semesta. Jadi, setiap simbol seperti huruf, surat, angka, juz, dan 'ain selalu diinterpretasikan dengan gambaran riil kehidupan manusia. 53

52Lihat : Muhammad Husein al-Dhahābī, Tafsìr wal Mufassirūn, 261 \& 273-274 \& Khalid Abdurrahmān al-Akk, Ușul al-Tafsīr wa Qawā'iduhu, (Beirut: Dār al-Nafá'is, 1986), 205.

${ }^{53}$ Lukman Abdul Qahar Sumabrata (dkk.), Pengantar Fenomenologi al-Qur'an Dimensi Keilmuan di Balik. Mushaf Usmani, 44.

TAJDID vol. XVI No. 1, Januari - Juli 2017|103 
Dalam diskursus al-Qur'an, terdapat sebuah corak penafsiran yang menggabungkan aspek isyari dan 'ilmi yang dikenal dengan istilah al-tafsìr al-isyāri al-'Ilmi. Tafsir dengan corak seperti ini berupaya mengungkap makna isyarat yang terkandung dalam ayat-ayat kauniyyah yang menerangkan tentang sistem kerja kosmos yang tunduk kepada kesatuan hukum Allah SWT. ${ }^{54} \mathrm{Jadi}$, proses simbolisme yang dilakukan banyak mengacu pada simbol-simbol objektif yang ada di luar alam dan di dalam diri manusia. Dalam hal ini, al-Qur'an mengandung dua jenis simbolisme utama, yaitu simbol-simbol macrocosmis di dalam jagad raya dan simbol-simbol microcosmis di dalam diri manusia. Dalam prakteknya, penafsiran yang mengacu pada simbol ini berusaha menjelaskan makna ayat-ayat al-Qur'an melalui perenungan langsung terhadap dunia luar dan dunia dalam. Hal ini juga telah dijelaskan oleh Abdurrahman al-'Akk dalam kitabnya yang berjudul Ușūl al-Tafsīr wa Qawā'iduhu. Ia menjelaskan bahwa altafsir al-ishāri al-'Ilmi menjelaskan tentang isyarat-isyarat qur'aniyah yang menunjukan kepada keagungan ciptaan Allah. ${ }^{55}$

Misalnya, Q.S. al-A'rāf [7]: 54 dan Q.S. al-Zumar [39]: 5

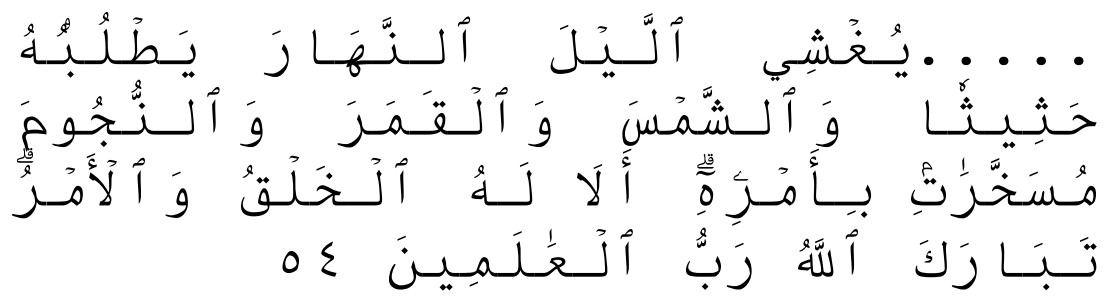

“...Dia menutupkan malam kepada siang yang mengikutinya dengan cepat, dan (diciptakan-Nya pula) matahari, bulan dan bintang-bintang (masingmasing) tunduk kepada perintah-Nya. Ingatlah, menciptakan dan memerintah hanyalah hak. Allah. Maha suci Allah, Tuhan semesta alam. ${ }^{156}$

${ }^{54}$ Baca: Abdurrahìm Yapono, Abd al-Karìm al-Qushayrī dan Sumbangannya dalam Tafsir Simbolik : Analisis Karya Lațà'if al-Ishārāt dalam Novizal Wendry, "Penafsiran Simbolik al-Qushayri Dalam Lațā'if al-Ishārāt" dalam Jurnal Studi al-Qur'an Vol. II, No. I, 2007, hlm. 290-293.

${ }^{55}$ Khālid Abdurrahmān al-'Akk, Ușūl al-Tafsìr wa Qawā'iduhu (Beirut: Dār al-Nafa'’ is, 1986), hlm. 217.

${ }^{56}$ Q.S. al-A'rāf [7]: 54 dalam Muhammad Taufiq, Qur'ān In Word Software Versi 1.3. 


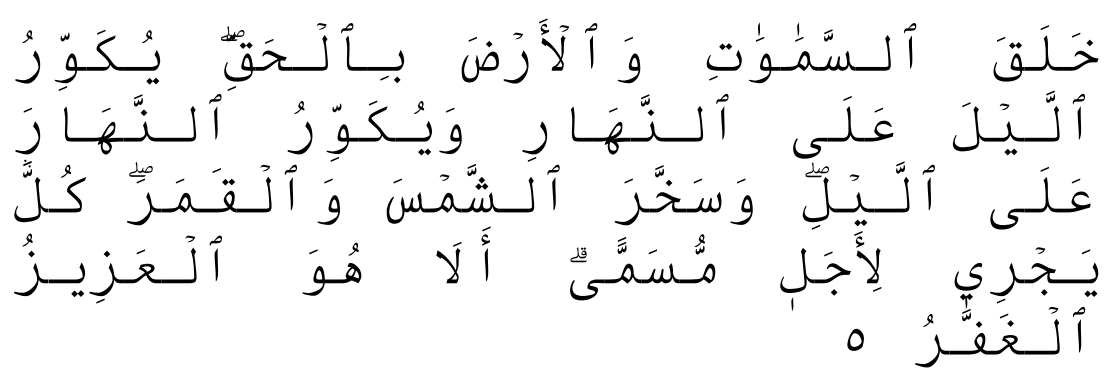

"Dia menciptakan langit dan bumi dengan (tujuan) yang benar; Dia menutupkan malam atas siang dan menutupkan siang atas malam dan menundukkan matahari dan bulan, masing-masing berjalan menurut waktu yang ditentukan. ingatlah Dialah yang Maha Perkasa lagi Maba Pengampun."'57 Dalam kitabnya tersebut, Khalid Abdurrabman al-Ak.k menjelaskan babwa kedua ayat di atas mengisyaratkan kepada perputaran bumi dan menunjukekan bahwa bumi itu bulat.

Pada kenyataannya, memang ada kemiripan di antara tafsir fenomenologi simbolik yang dipaparkan oleh Lukman dengan tafsir isyari dan tafsir 'ilmi dalam kerangka tafsir konvensional. Akan tetapi, tafsir fenomenologi tidak dapat dikategorikan ke dalam kedua model penafsiran tersebut. Sekalipun dalam tafsir isyari misalnya terdapat tradisi menafsirkan huruf-huruf al-Qur'an sebagaimana fenomena yang terjadi pada tafsir fenomenologi simbolik, tetapi semua itu berangkat dari al-Qur'an sebagai bahasa verbal. Dengan demikian, ada perbedaan yang signifikan antara tafsir fenomenologi simbolik dengan tafsir isyari maupun tafsir 'ilmi yang terletak pada asumsi dasar dan objek dari tafsir fenomenologi simbolik. Objek penafsiran simbolik dalam buku Pengantar Fenomenologi al-Qur'an bukanlah bahasa verbal melainkan format dan struktur al-Qur'an, seperti huruf, angka, nama-nama surat, juz, dan tanda 'ain. Jadi, penafsiran yang ingin diungkapkan oleh pengarang adalah makna simbolik di balik keunikan susunan format dan struktur mushaf al-Qur'an. Hal inilah yang menyebakan tafsir fenomenologi simbolik dalam pemaparannya mengenyampingkan aspek-aspek lain, seperti aspek bahasa yang sebenarnya akan membawa kita kepada pedoman hidup karena mengandung hukum syar'i.

${ }^{57}$ Q.S. az-Zumar [39]: 5 dalam Muhammad Taufiq, Qur'ān In Word Software Versi 1.3.

TAJDID vol. XVI No. 1, Januari - Juli 2017|105 
Klaim sebagian orang yang menganggap bahwa metodologi yang ditawarkan oleh Lukman A.Q. Sumabrata merupakan bagian dari kategori tafsir isyari juga ditanggapi oleh para pengamat studi 'ulūm al-Qur'an seperti Ahsin Sakho Muhammad seorang Rektor Insitut Ilmu al-Qur'an (IIQ) dalam sebuah seminar tentang buku "Membaca dan Memahami Konstruksi al-Qur'an" di Jakarta. Ia berpendapat bahwa metode ini hanya bisa dimasukkan ke dalam kemukjizatan alQur'an dari segi angka (I'jä 'adadî) bukan termasuk ke dalam bagian dari tafsir isyari. Alasannya karena metode ini selalu berkiblat dan menggunakan bilangan sebagai dasar kajiannya. Hal ini hampir sama dilontarkan oleh Prof. Dr. Rifat Sauqi Nawawi, seorang guru besar Tafsir Hadith di UIN Syarif Hidayatullah Jakarta dan Masdar Mas'udi, ketua PBNU.58

Tanggapan seperti ini wajar mengingat upaya yang dilakukan oleh Lukman AQ Sumabrata dalam mengungkap rahasia-rahasia dari format dan struktur al-Qur'an bukanlah hal yang pertama kali ditemukan dalam kajian al-Qur'an. Sebelumnya, telah muncul sebuah metode yang berusaha mengungkapkan aspek keunikan dari fenomena-fenomena al-Qur'an tersebut. Di antaranya adalah metode hisābul jumal yang paling banyak digunakan oleh para peneliti dalam mengungkapkan makna di balik fenomena-fenomena al-Qur'an khususnya fenomena angka dan huruf. Jenis perhitungan ini dianggap perhitungan yang paling terdahulu di antara apa yang dikenal dengan kemukjizatan angka. Cara kerjanya berlandaskan dengan mengganti semua huruf dengan angka. Misalnya, huruf alif dituliskan dengan angka 1, huruf $b a^{\prime}$ dituliskan dengan angka 2 , dan seterusnya sesuai dengan pola abjad hawwaz (urutan abjadiah). Metode ini juja telah mendapat banyak kritikan dari ilmuwan-ilmuwan muslim. Di antaranya, jumlah kata al-Bayyinah (البينة) adalah 98. Jika kita menuliskan setiap huruf dari kata ini dengan angka, maka jumlahnya adalah 98. Ini adalah urutan surat al-Bayyinah dalam al-Qur'an. Perhitungan seperti ini juga terjadi pada kata al-Hadid (الحديد) yang penjumlahan huruf-hurufnya sesuai dengan urutan surat al-Hadid dalam al-Qur'an. Seandainya keadaan ini terus menerus terjadi pada metode hisāb al-jumal, maka hasil yang diperoleh dapat diterima dan

${ }^{58}$ Majalah Khilafah, Launching dan Bedah Buku Membaca dan Mehamami Konstruksi al-Qur'an, Edisi 54/th. III/2007/1-4, Februari/13-26 Muharram 1428 H, 9 dalam Didin Rohaedin, "Penyalinan Mushaf Uthmani Menurut Iskandar Agun Sumabrata,” Skripsi Fakultas UIN Sunan Kalijaga, 2008, 75. 
tidak ada kemungkinan terjadinya faktor kebetulan. ${ }^{59}$ Namun, keadaan ini hanya terjadi pada dua surat dari jumlah seluruh surat dalam al-Qur'an.

Bagaimanapun, bukan berarti kita harus mengabaikan fenomena ayat, surat, dan huruf secara keseluruhan. Kajian dan penelitian secara sistematis terhadap susunan ayat-ayat al-Qur'an menunjukan bahwa harmonisasi dan koherensi tidak hanya terbatas pada makna dan berbagai petunjuk melalui kata-katanya, melainkan juga terdapat dalam jumlah kata-kata tersebut dan pengulangan huruf-hurufnya. ${ }^{60}$ Inilah yang menjadi aspek lain dari kemukjizatan al-Qur'an. Yang harus diperhatikan bagi para peneliti dalam mengkaji fenomenafenomena al-Qur'an ini adalah tidak mengenyampingkan mukjizat gaya bahasa dan mukjizat lainnya yang terkandung dalam kitab suci alQur'an.

\section{Kesimpulan}

Tafsir fenomenologi simbolik di sini bukanlah sebuah penafsiran terhadap kandungan ayat-ayat al-Qur'an sebagaimana yang sudah dikenal pada umumnya. Akan tetapi, penafsiran ini dilakukan untuk menemukan pesan-pesan keilmuan di balik unsur-unsur simbolik dalam al-Qur'an, seperti huruf, angka, surat, juz, dan tanda 'ain. Jadi, permasalan dalam metode ini adalah tentang benarkah al-Qur'an itu hanya terdiri dari susunan ayat yang jumlahnya 6236? Mengapa alQur'an disusun dalam bagian-bagian yang disebut juz, dan mengapa jumlahnya ada 30? Apakah tanda 'ain hanya diartikan sebagai tanda berhenti membaca? Mengapa yang digunakan huruf 'ain bukan huruf lainnya? dan lain sebagainya.

Dalam mengungkapkan makna-makna simbolik tersebut, Lukman menggunakan pendekatan spiritual sehingga sulit dijangkau validitasnya. Hal inilah yang menjadikan tafsir fenomenologi simbolik yang diusung oleh Lukman A.Q. Sumabrata mirip dengan tafsir isyari karena keduanya berupaya mengungkap makna batin yang terkandung di balik fenomena-fenomena al-Qur'an. Akan tetapi, tafsir fenomenologi simbolik ini tidak dapat dikategorikan ke dalam model penafsiran tersebut. Hal ini dikarenakan adanya perbedaan yang

${ }^{59}$ Hisyam Thalbah (dkk.), Ensiklopedia Mukjizat al-Qur'an dan al-Hadith, terj. Syarif Hade Masyah (dkk.), Volume 9 (Sapta Sentosa), 43-44.

${ }^{60}$ Hishām Talbah (dkk.), Ensiklopedia Mukjizat al-Qur'an dan al-Hadith, terj. Syarif Hade Masyah (dkk.), Volume 9 (Jakarta: Sapta Sentosa, 2009), 38.

TAJDID Vol. XVI No. 1, Januari - Juli 2017 |107 
signifikan antara tafsir fenomenologi simbolik dan tafsir isyari yang terletak pada asumsi dasar paradigma tafsir fenomenologi simbolik. Objek penafsiran simbolik dalam buku Pengantar Fenomenologi al-Qur'an bukanlah bahasa verbal melainkan format dan struktur al-Qur'an, seperti huruf, angka, nama-nama surat, juz, dan tanda 'ain. Maka, kajian mengenai fenomenoogi simbolik al-Qur'an tidak dapat dikategorikan sebagai kajian tafsir al-Qur'an, namun lebih tepat dikategorikan sebagai kajian mukjizat al-Qur'an.

\section{Daftar Pustaka}

Gusmian, Islah. Khazanah Tafsir Indonesia Dari Hermeneutik Hingga Ideologi. Jakarta Selatan: Teraju. 2003.

At-Tubany, Ziyad Ul-Haq. Struktur Matematika al-Qur'an. Surakarta: Rahma Media Pustaka. 2009.

Abror, Indal. "Metodologi Fenomenologi Simbolik dalam Menafsirkan al-Qur'an" Jurnal Studi Ilmu-ilmu al-Qur'an dan Hadits. Vol . No. 1. Th. 2000.

Semiawan, Conny R. Metode Penelitian Kualitatif: Jenis, Karakteristik dan Keunggulannya. Jakarta: Grasindo. 2010.

Sumabrata, Lukman Abdul Qahar (dkk.). Pengantar Fenomenologi alQur'an Dimensi Keilmuan di Balik Mushaf Usmani . Jakarta: Grafikatama Jaya. 1991.

Sumabrata, Iskandar Agung. Pesan-pesan Numerik al-Qur'an. Jakarta Selatan: Republika. 2006.

Lasmana, Nunung dan Suhendra, Ahmad. "Tafsir Fenomenologi Simbolik al-Qur'an” dalam Jurnal Empirisma. Vol. 24. No. 1 Januari 2015.

Muniron. Epistemologi Ikhwan as-Shafa. Yogyakarta: Pustaka Pelajar. 2011.

Partanto, Pius A. \& al-Barry, M. Dahlan. Kamus Ilmiah Populer. Surabaya: Arkola. t. th.

Saksono, Lukman \& Anharudin. Pengantar Psikologi al-Qur'an Dimensi Keilmuan di Balik Mushaf Usmani. Jakarta: Grafikatama Jaya. 1992. 
al-Akk, Khālid Abdurrahmān. Ușul al-Tafsir wa Qawā'iduhu. Beirut: Dār al-Nafā'is. 1986.

adz-Dzahabi, Muhammad Husein. Tafsīr wal Mufassirūn. Kairo: Maktabah wa Hibbat. t.th

al-Qaț̣ān, Manna' Khalìl. Mabāhiṣ Fì 'Ulūm al-Qur'ān. t.tp : Mansyurāt al-'Așri al-Hadith. 1990.

Keeler, Annebel. "Tafsir Sufistik Sebagai Cermin: al-Qushairy Sang Mursyid dalam Karyanya Lațā'iful Ishārāt" Jurnal Studi alQur'an. Vol. II. No. I. 2007.

Kuntowijoyo. Islam Sebagai Ilmu: Epistemologi, Metolodogi, dan Etika. Yogyakarta: Tiara Wacana. 2007.

Kuntowijoyo. Paradigma Islam: Interpretasi Untuk Aksi. Bandung: PT. Mizan Publika. 2008.

Nurdin, Asep ."Karakteristik Tafsir Sufi: Telaah Atas Metodologi Penafsiran al-Qur'an Ulama Sufi" dalam Jurnal Studi al-Qur'an dan Hadith. Vol. 3. No. 2 Januari 2003.

at-Tustari. "Tafsìr al-Tustarī" dalam http://www.altafsir.com, diakses pada 3 November 2012.

As-Suyūṭi. al-Itqān Fī 'Ulūm al-Qur’ān . Beirut: Da>r al-Fikr. 1951. Ahmad Jaeni, Skripsi Fakultas Ushuluddin UIN Sunan Kalijaga, Yogyakarta, 2006.

Saifuddin, "Hermeneutik Sufi: Menembus Makna di Balik Kata" dalam Sahiron Syamsuddin (ed.) Hermeneutik al-Qur'an dan Hadith (Yogyakarta: eLSAQ Press, 2010)

M. Grant, Robert dan David Tracy. Sejarah Singkat Penafsiran alKitab terj. Agustinus Maleakhi. Jakarta: PT BPK Gunung Mulia. 2000.

Tukan, Paulus. Mahir Berbahasa Indonesia 3. Yudhistira Ghalia Indonesia, t.th.

Rahmat, Jalaluddin. Tafsir Sufi al-Fātihah. Bandung: Rosdakarya. 1999.

al-Aqqad, Abbas Mahmud. Filsafat Qur’an terj. Tim Pustaka Firdaus. Jakarta: Pustaka Firdaus. 1986.

Anwar, Rosihon dan Sholihin, Mukhtar. Ilmu Tasawuf. Bandung: Pustaka Setia. 2000.

TAJDID vol. XVI No. 1, Januari - Juli 2017 |109 
Nunung Lasmana

Abdurrahīm Yapono, Abd al-Karīm al-Qushayrī dan Sumbangannya dalam Tafsir Simbolik: Analisis Karya Lațā'if al-Ishārāt dalam Novizal Wendry, "Penafsiran Simbolik alQushayrī Dalam Lațā'if al-Ishārāt" dalam Jurnal Studi alQur'an Vol. II, No. I, 2007.

Qur'ān In Word Software Versi 1.3.

Didin Rohaedin, "Penyalinan Mushaf Uthmani Menurut Iskandar Agun Sumabrata”, Skripsi Fakultas UIN Sunan Kalijaga, 2008.

Thalbah, Hisyam (dkk.). Ensiklopedia Mukjizat al-Qur'an dan alHadith terj. Syarif Hade Masyah (dkk.). Volume 9. T.T: Sapta Sentosa. t.th. 